Intersections

Canadian Journal of Music

Revue canadienne de musique
Intersections

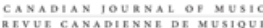

\title{
Editorial: Nickel- and Dime-ing
}

\section{Murray Dineen}

Volume 29, numéro 1, 2009

URI : https://id.erudit.org/iderudit/039106ar

DOI : https://doi.org/10.7202/039106ar

Aller au sommaire du numéro

Éditeur(s)

Canadian University Music Society / Société de musique des universités canadiennes

ISSN

1911-0146 (imprimé)

1918-512X (numérique)

Découvrir la revue

Citer ce document

Dineen, M. (2009). Editorial: Nickel- and Dime-ing. Intersections, 29(1), 3-5.

https://doi.org/10.7202/039106ar

Tous droits réservés (C) Canadian University Music Society / Société de musique des universités canadiennes, 2009
Ce document est protégé par la loi sur le droit d'auteur. L’utilisation des services d'Érudit (y compris la reproduction) est assujettie à sa politique d'utilisation que vous pouvez consulter en ligne.

https://apropos.erudit.org/fr/usagers/politique-dutilisation/ 


\section{EDITORIAL: NICKEL- AND DIME-ING}

We're nickel- and dime-ing ourselves to death.

Intersections has just scraped through a lawsuit, and in doing so come close to a major financial blow that could have done us in, us and many other Canadian scholarly journals like us. We were named as a third party defendent by one of our commercial aggregators (who for the moment shall remain nameless here) in a lawsuit filed by the freelance writer Heather Robertson. Ms. Robertson is suing this aggregator as well as other media outlets for damages: they distributed her work electronically for which they did not have electronic rights and did not pay any additional royalities. The suit against our aggregator was a class action, representing all freelancers for publications distributed by said aggregator, who in turn named some two hundred groups as third- and fourthparty defendents, these including Intersections. Our aggregator, had they lost the suit, would have sought damages from us for articles reproduced where the author had not clearly signed away rights to compensation. Had they won the suit, journals might have still been liable under the indeminification clause for a portion of the aggregator's legal costs. Fortunately, through the auspices of a lawyer, Davis LLP of Toronto, not-for-profit journals such as ours have been excluded from the suit. We're free, albeit only by the skin of our teeth.

If we were not put in financial straits by this development, we were certainly in financial narrows. CUMS/SMUC as a society has a small capital reserve fund, accumulated gradually over time, meant to cover exigencies involved in society affairs. But quite probably it would not have been sufficient to meet the sum demanded in this lawsuit. And in this regard, Intersections might well have taken down CUMS/SMUC with it, had it gone under while paying a court settlement. We did win generous funding from SSHRC in 2007, but those funds were given under a contractual understanding, and funding a major lawsuit does not normally fit under SSHRC's rubric. We were lucky, just lucky.

We have taken and will be taking steps to prevent a recurrence of this situation. Principal among these is putting Intersections online through the services of Érudit, a service provided by the Université de Montréal, through which some of you may be accessing this editorial now. If we should lose funding, we could jettison mthe paper version and continue onward, presumably, with a less expensive online version. Many, myself included, prefer the paper form.

My sense of the situation is (as I said above) we're just nickel- and dimeing ourselves here. CUMS/SMUC is the central society for Canadian academic interest in music, and Intersections is its house journal-the central vehicle for Canadian academic publication in music (which, it must be said, also publishes work by our friends from outside Canada). The severity of the lawsuit is not that it could have put CUMS/SMUC and Intersections out of business, but 
that it threatened the central society for scholarly music research in Canada. Think about it for a moment: for most of you, that's a threat to the very thing by which you earn your livelihood. Without a national institutional presence, it becomes markedly more difficult to defend a scholarly field in Canada. Society and journal-these are the forums by which we represent ourselves to the rest of the world, for better or for worse. And both came very close to the edge.

No doubt there are specialized societies and specialized journals on the Canadian scene. These, however, are closely tailored to our needs as individuals. They don't fulfill our collective need. No doubt there are the major American societies, which sometimes represent themselves as international in mandate, but which all too readily default to the values of the country in which they are produced. Laudable as those values are, they don't necessarily respond to the needs of music scholarship in our country, or elsewhere for that matter.

How would it look if Intersections were forced into bankruptcy and as a consequence dragged CUMS/SMUC with it? How would that reflect upon the values of Canadian music scholarship as an independent national enterprise? How would that reflect upon Canadian music scholars?

It would make us look a lot like a nickel-and-dime operation.

Try a thought experiment. Imagine AMS and JAMS - or SEM and Ethnomusicology, or the Society for American Music and its house journal, or any other comparable society and journal combination-folding for lack of funds as the result of a lawsuit such as ours. Would there be a major hue and cry? Would the scholars involved be embarrassed and ashamed? Would they do their level best to avoid such a situation, even if that involved the considerable expenditure of private resources?

Let's start loonie- and toonie-ing ourselves back to life. We should begin by making ourselves worth more than just nickels and dimes.

I like to describe CUMS/SMUC and its offspring as "unscripted." In other, larger, and usually foreign academic situations, geography and temperament have led to convergence in music scholarship. The agendas of scholarly meetings, the nature of scholarly awards, the proceedings of scholarly conferencesthese all seem predetermined, either by small cliques of vested interests or with the aim of offending no one. The same faces seem to appear and reappear, the same issues, the same articles and books, albeit under new titles. Scholarship seems scripted: lights, action, and ... more of the same.

Not so CUMS/SMUC, or Intersections for that matter. And that's our saving grace. Rarely are things predictable-conferences, journal issues, CUMS/ SMUC executive board meetings. And if one or two faces tend to reappear, in print or on the podium of the annual general meeting, all too rarely is their behaviour predictable, certainly never scripted. I believe this lack of script is a product of several factors, not just the always touted Canadian geography with its distances that makes the formation of cliques a physical improbability, even with email. As scholars with a closeted colonial history we defer to research cliques made elsewhere-largely those of our American cousins. The great bulk of us are "working" scholars caught up with teaching the "fundamental" skills of music, and thus our research tends to be accomplished in a haphazard 
and unscripted fashion, as if it were a hobby like exotic haberdashery or the collection of rare stamps. Unlike foreign colleagues whose collective vested interests allow them to cluster in themed conference "sessions" that have about them a sense of agenda, we tend to bring our research forth nakedly as individuals. Going to CUMS/SMUC at Congress is like "show and tell": "This is what I'm working on right now." No one is out to make a career at Congress, but merely to bring out what's been worked on over the winter, show it off, and take it back to the workshop. Its freshness and sincerity should endear this kind of scholarship to us.

I note that the annual CUMS/SMUC dues for full-time faculty is sixty dollars. AMS has a special category of regular membership for Canadians on their website, with dues of ninety dollars. Which of the two has a greater impact upon my life as a Canadian scholar? Does AMS (or IASPM International, or SMT, or like-minded institutions) have input to SSHRC through the Canadian Federation of the Humanities and Social Sciences (and thus give advice on the specifically Canadian needs for research funding)? Does AMS have a Standing Committee for Institutional Members-members, that is, of Canadian institutions of learning that are funded provincially, with all the problems that entails? Does AMS respond to particularly Canadian issues at its annual conference-both Canadian content in paper sessions and issues like the shutting down of the CBC Vancouver orchestra?

Let's loonie and toonie ourselves by paying our CUMS/SMUC annual dues before we renew membership in AMS. Let's pay full conference registration, even if we can attend on only one day. Let's send one article to Intersections for every article we send to an offshore journal. Let's propose one paper yearly to the annual CUMS/SMUC conference, especially if it's in someplace out of the way-for that matter, even if it's in Central Canada. Let's raise our dues to match if not exceed what AMS charges Canadians, and let's pay them first. That should give us a decent capital reserve fund, one strong enough to take on unpredictables like our recent lawsuit.

The alternative is just to keep on nickel- and dime-ing, to keep shortchanging ourselves, both in the eyes of the world and worse yet in our own eyes. Surely we're worth more than that.

(In closing, let me say that I am leaving the position of English-language editor in the very capable hands of Brian Locke. I will assume the position of officer for external relations, which should allow me to devote more time to our Internet presence and to spreading our reputation around the world. I thank everyone who has made my brief tenure as editor just as rewarding as it was stimulating.)

Murray Dineen 